いると, 塩の影響のため, 色が濃くなり硫酸イオンに対 して負の誤差を与える。 $\mathrm{NO}_{3}$ - は $50 \mathrm{ppm}, \mathrm{CO}_{3}{ }^{2-}{ }^{27}$ は $20 \mathrm{ppm}$ 以上存在すると妨害する。100 ppm の $\mathrm{Ca}^{2+}$, $\mathrm{Mg}^{2+}$, および $10 \mathrm{ppm}$ の $\mathrm{Al}^{3+}$ の共存は, ほとえど妨 害しなかった。

\section{[VI] 蒸留水中の硫酸イオンの含有量}

$0.02 \mathrm{ppm}$ という微量の硫酸イオンを定量するについ ては, 使用する蒸留水中の硫酸イオンの含有量が問題に なってくる。蒸留水中の硫酸イオンの濃度を $\alpha \mathrm{ppm}$ と すれば, 今まで示してきた図の検量線の横軸の硫酸イオ ンの濃度は, この $\alpha$ を加算したものになる。そしてこのの $\alpha$ 求めることは大変困難な問題である。しかし, これ を求めるのには, 外部からの污染を最小限度に食い止め て, 蒸発濃縮し, その濃縮水中の硫酸イオンを本法で定 量して, 計算で求める以外に良法はない*8。

蒸留水を $m$ 倍に濃縮して, 本法で光度定量し, 上に示 した検量線を用いて求めた硫酸イオンの濃度（図の横軸 の值）が $a \mathrm{ppm}$ であったとすれば， $\alpha=a / m-1$ なる関 係が成立するはずである。著者らの使用した蒸留水中の

*7 $\mathrm{CO}_{3}^{2}$ - は炭酸ナトリウムを用い, その濃度は計算から求めた。

*8 $0.05 \mathrm{ppm}$ 以下の濃度の硫酸イオンの定量法が現在知られていな いから.
この $\alpha$ を求めるため, いろいろ検討した結果，その值は 最大 $0.02{ }_{4} \mathrm{ppm}$ 位であろうという結論を得た。

実験は，なるべくきれいな 部屋で，30～50 cc の蒸留 水を電熱器を用いて約 $10 \mathrm{cc}$ に,なるべく短時間（20〜 30 分）に加熱濃縮する。この場合, 加熱に赤外線ランプ を使用してみたが, 電熱器で十分であることが知れた。 また空気中からの污染は問題とするにたりなかったが， 蒸発ザラからくる污染は十分注意しなければならないこ とが知れた。すなわち，古い白金蒸発ザラとか，石英蒸 発ザラを使用すると，よほど注意して清浄にしても，容 器からきわめて微量の硫酸イオンが蒸発中にとけ出して くることがあった。著者らは, 新品の磁製蒸発皿を使用 することによって容器からの污染をほとんどなくするこ とができた。

なお，蒸留水については，イオン交換樹脂で精製した ものや，その他のものについてもいろいろ検討したので あるが,これらのことについては, 今後さらに検討して ゆきたいと考えている。

終りに本研究費の一部は文部省の科学研究費によった ことを記して感謝の意を表する。

（昭和 32 年 4 月, 日本化学会第 10 年会講演）

（東京大学理学部化学教室, 東京都文京区）（昭和 32 年 7 月 12 日受理）

tert-塩化アミル, tert-臭化アミルの回転異性体

林通郎

tert-塩化アミル $\left(\left(\mathrm{CH}_{3}\right)_{2} \mathrm{CClCH}_{2} \mathrm{CH}_{3}\right)$, tert-臭化アミル $\left(\left(\mathrm{CH}_{3}\right)_{2} \mathrm{CBrCH}_{2} \mathrm{CH}_{3}\right)$ のラマン効果, 赤外線吸収気気体, 液体, 固体に扔いて測定し, てれらの分子の回転異性体について考察した。こ れらの分子はいずれも気体，液体において $\mathrm{X} \cdots \mathrm{CH}_{3}(\mathrm{X}$ ，八ロゲン）に関してトランス，中間の 2 種の回転異性体が存在し, 固体ではそのうち一方のみとなる。基準振動の計算を 1,2-シクロル-2メチルプロパンの結果を基礎として摂動論による近似計算で行い，ての結果を参考とし，また類似 分子である 1,2-ジクロル-2-メチルプロパン, 1,2-ジブロム-2-メチルプロパンの結果と比較して 固体で存在する分子形は中間形であるてとを決定した。さらに振動スペクトルの㷌属を行い, $\left(\mathrm{CH}_{3}\right)_{2} \mathrm{CXCH}_{2} \mathrm{Y}$ 形分子 $\left(\mathrm{X}=\mathrm{Cl}, \mathrm{Br}, \mathrm{Y}=\mathrm{Cl}, \mathrm{Br}, \mathrm{CH}_{3}\right) 4$ 種について結果を比較した。

序

論

著者はすでに 1,2-ジクロル-2-メチルプロパン1) 1,2ジブロム-2-メチルプロパン2）について回転異性体が存

1) 林, 本誌 78, 536 (1957).

2) 林, 本誌 78, 1749 (1957).
在することを報告した。その結論は気体, 液体において $\mathrm{X} \cdots \mathrm{Y}$ について $(\mathrm{X}, \mathrm{Y}=\mathrm{Cl}, \mathrm{Br})$ トランス形, 中間形 の両分子形が存在, 固体ではトランス形の及となること がわかった。さらに 1,2-ジクロル-2-メチルプロパン, 1,2-ジブロム-2-メチルプロパンの振動スペクトルは非 常に似ていることが注目された。 
以下報告する $\left(\mathrm{CH}_{3}\right)_{2} \mathrm{CXCH}_{2} \mathrm{CH}_{3}$ 形分子 $(\mathrm{X}=\mathrm{Cl}$, Br）は，分子の形としては 1,2-ジクロル-2-メチルプロ パン，1,2-ジブロム-2-メチルプロパンと似ているが, こ れらと異なり，結合能率の相互作用が考えられず，また 分子形により双極子能率が変化しない点が注目される。 このような点が回転異性体の性質にいかに関係するかを 知ること悱常に興味があることと思われる。

\section{試 料 と実 験}

測定に使用した試料はつぎのように合成した。

tert-塩化アミル，tert-臭化アミル共に tert-アミル アルコールに濃塩酸, 濃臭化水素酸を加え約 2 時間加熱, 有機層を分離し，泠水で何度も洗い，分留した。 tert-塩化アミル， bp $85^{\circ} \mathrm{C}$; tert-臭化アミル， bp $108^{\circ} \mathrm{C}$, 出発原料の tert-アミルアルコールがないこと は赤外線吸收でしらべた。

ラマン効果は液体, 固体共に普通の方法で行い, 固化 には液体窒素を用いた。

赤外線吸収は気体, 液体共に岩塩, 系化カリウムプリ ズムを用いて $4000 〜 400 \mathrm{~cm}^{-1}$ の波数範囲で測定した。

Baird, Hilger, Perkin-Elmer 21 分光器を使用した。 結果安第 1,2 表，第 $1,2,3,4$ 図（次頁）に示した。

\section{回転異性体の存在}

\section{tert-塩化アミル}

第 1 表の液体，固体のラマンスペクトルをみると液体

第 1 表 $\quad$ tert-塩化アミルの振動スペクトル $\left(\mathrm{cm}^{-1}\right)$

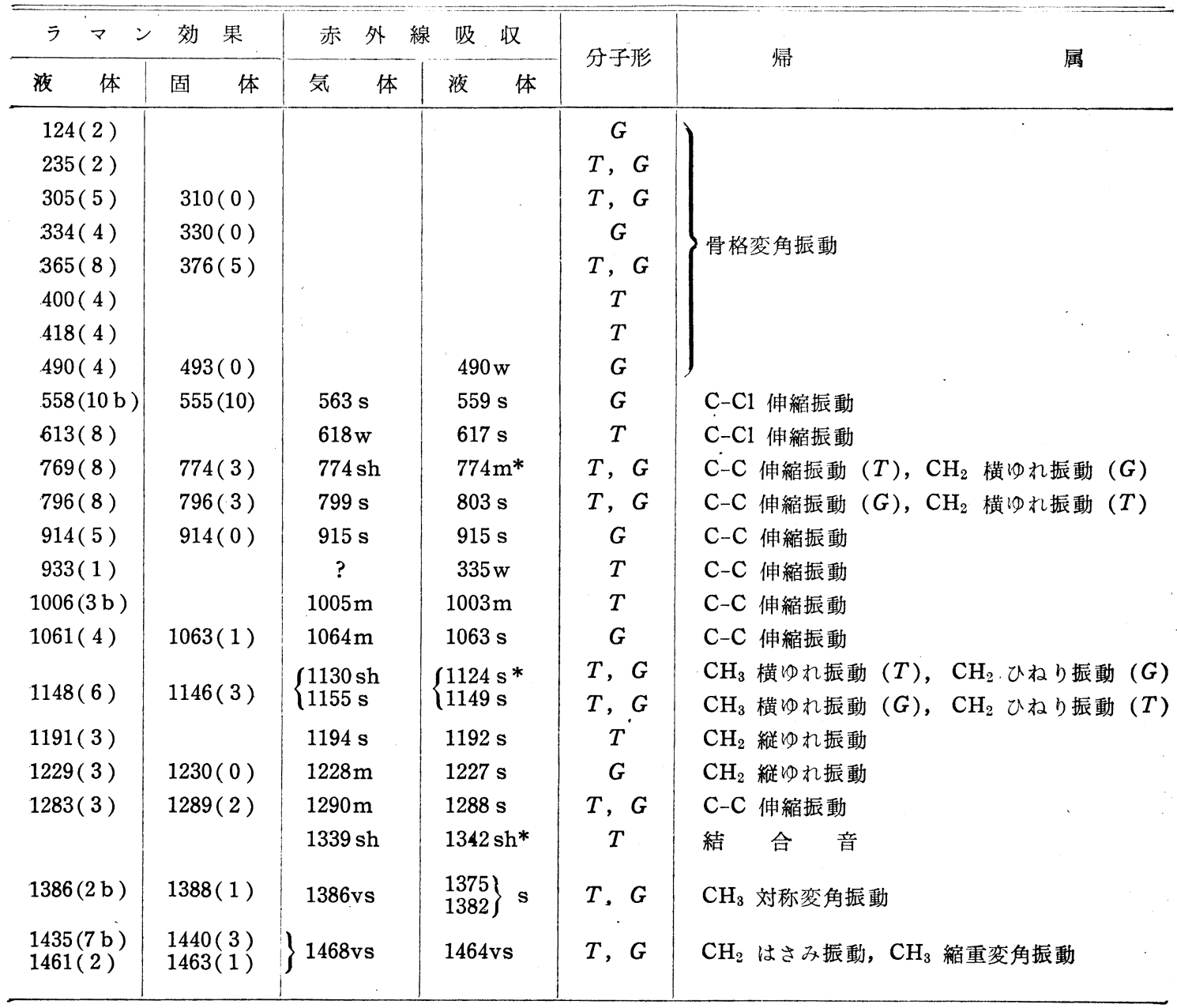

$1500 \mathrm{~cm}^{-1}$ 以上のスペクトルは省略する.この中には $2900 〜 3000 \mathrm{~cm}^{-1}$ 付近には $\mathrm{CH}$ 伸縮振動がある：

*のスペクトルは低温にすると強度を増するのである。 
第 2 表 $\quad$ tert-臭化アミルの振動スペクトル $\left(\mathrm{cm}^{-1}\right)$

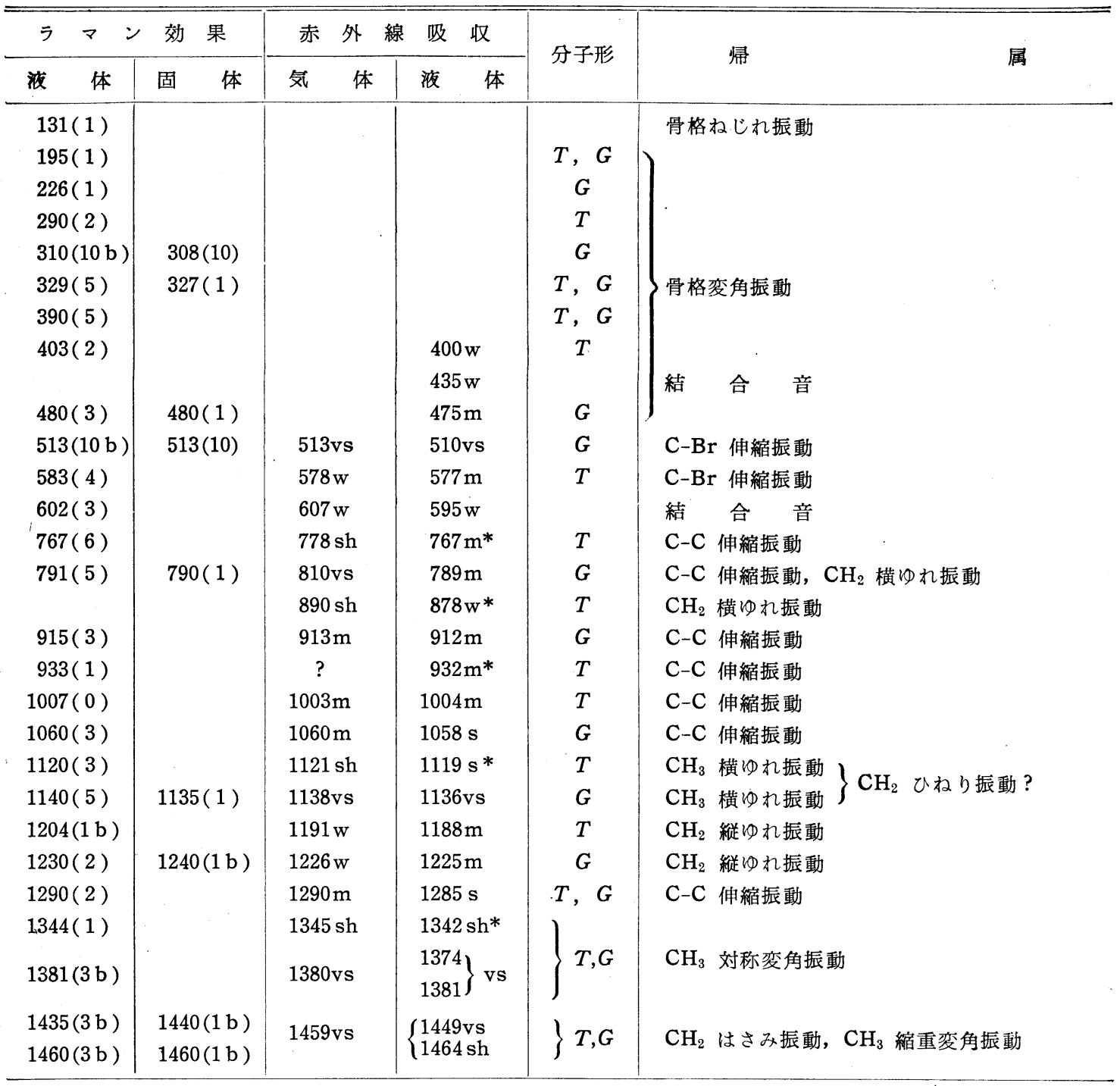

$1500 \mathrm{~cm}^{-1}$ 以上のスペクトルは省略した。この中には $2900 \sim 3000 \mathrm{~cm}^{-1}$ 付近の $\mathrm{CH}$ 伸縮振動がある.

*は低温 $\left(-120^{\circ} \mathrm{C}\right)$ で強度を增すもの.

でかなり強いスペクトルが固体ではみられない。

骨格変角振動：124，235，400，418 $\mathrm{cm}^{-1}$ が固体で発 見できず, $305 \mathrm{~cm}^{-1}$ の相対強度がかなり減少している。 このうち $124,235 \mathrm{~cm}^{-1}$ の消失は液体でも弱いスペク トルであるため不確実であるが $400,418 \mathrm{~cm}^{-1}$ は確実 に消失している。

C-C1 伸縮振動：液体で $558,613 \mathrm{~cm}^{-1}$ に存在する が，このうち $613 \mathrm{~cm}^{-1}$ が固体で消失する。

他のラマンスペクトルには確実に消失していると考え られるものはない。また赤外線吸収は固体で測定できな
かったので比較できなかっだ。しかし第 1 図に示した ように低温において液体の赤外線吸収はその強度がかな り変化することがわかった。とくに $799,774 \mathrm{~cm}^{-1}$ の 吸収の組湿常 $\left(25^{\circ} \mathrm{C}\right)$ では $774 \mathrm{~cm}^{-1}$ が $799 \mathrm{~cm}^{-1}$

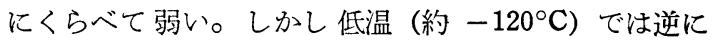
$799 \mathrm{~cm}^{-1}$ が弱くなる。1124, $1149 \mathrm{~cm}^{-1}$ の組でも同様 なことがあり，強度逆転がみられる。また $1342 \mathrm{~cm}^{-1}$ にある shoulder にも強度変化がみられる。

\footnotetext{
*との分子の融点がかなり低いため固体の赤外線吸収に使 用した䒾 置では固化できなかった。
} 


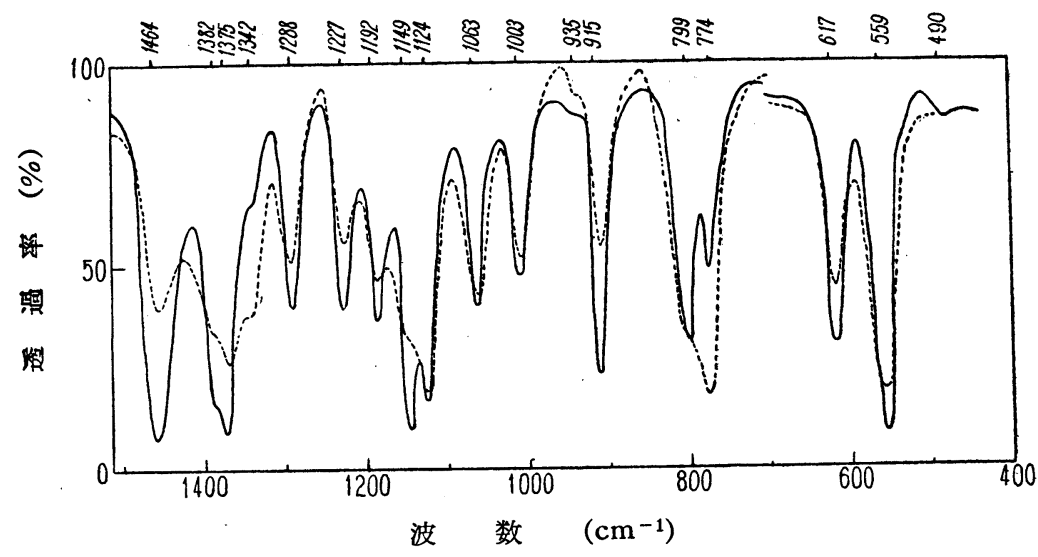

液体: 一 常温 $\left(25^{\circ} \mathrm{C}\right), \cdots$ 低温 $\left(-120^{\circ} \mathrm{C}\right)$

第 1 図 tert-塩化アミルの赤外線吸収

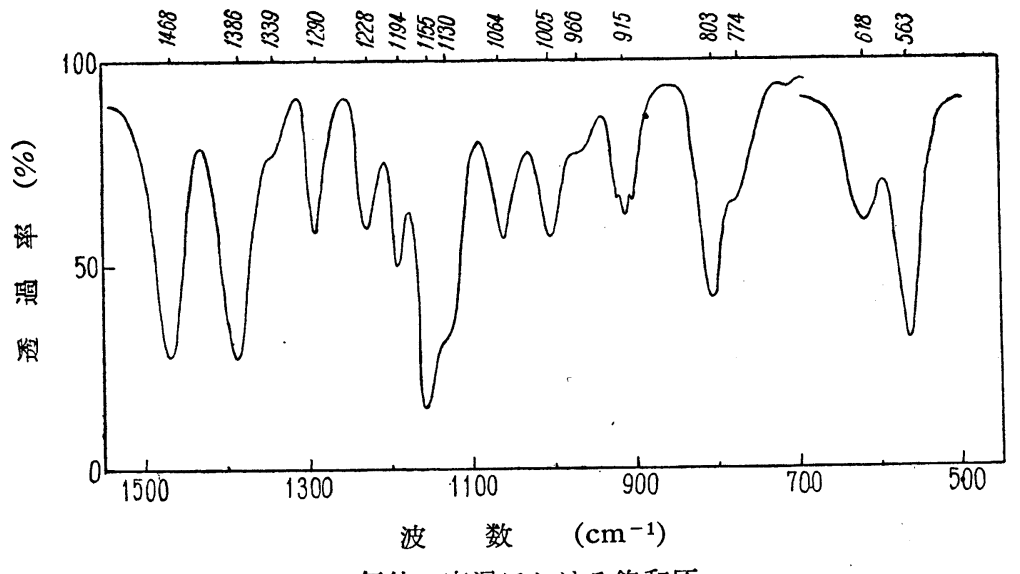

気体, 室温に打ける飽和圧

第 2 図 tert-塩化アミルの赤外線吸収

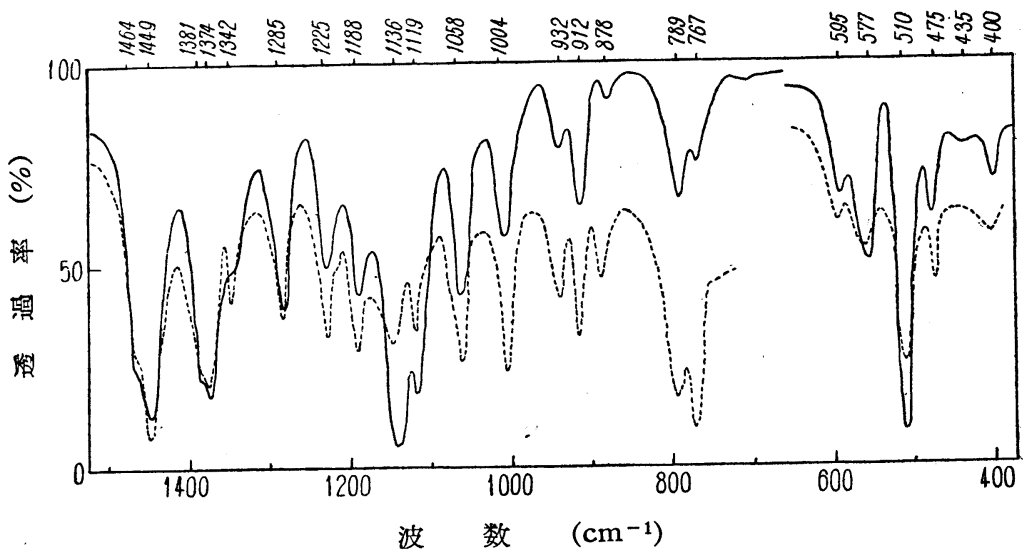

液体：一常温 $\left(25^{\circ} \mathrm{C}\right), \cdots$ 低温 (約 $\left.-120^{\circ} \mathrm{C}\right)$

第 3 図 tert-臭化アミルの赤外線吸収
このようにスペクトルの強度が 変化することと,少数ではあるが， 重要なスペクトルが消失している ので液体で 2 種の回転異性体が存 在, 固体ではこのうち一方のみに なることは確実である。

気体においても 2 種の回転異性 体が存在することは固体で消失す る $613 \mathrm{~cm}^{-1}$ のスペクトルが赤外 線吸収で存在することから明らか である。

\section{tert-臭化アミル}

第 3 表 (次頁)，第 3,4 図から tert-塩化アミルと同様な回転異 性体の存在の証明ができる。

骨格変角振動：固体で発見でき ないラマンスペクトルは多数ある が，液体においても非常に弱いス ペクトルが多いので確実なものは ない。 $390 \mathrm{~cm}^{-1}$ はやや強いスペ クトルで同程度の強度をもつ 329 $\mathrm{cm}^{-1}$ が固体で存在するから，存 在するものならば確実に発見でき るはずである。実際には見あたら ない。このため完全消失したもの か，またはかなり強度を減じたも のと推定される。

$\mathrm{C}-\mathrm{Br}$ 伸縮振動：液体では513, $583 \mathrm{~cm}^{-1}$ に存在する。このうち $583 \mathrm{~cm}^{-1}$ は固体で消去する。

他に固体で完全に消失するスペ クトルは発見できない。この分子 についても tert-塩化アミルと同 様赤外線吸収を固体で測定するこ とができなかったが，第 3 図に示 したように低温において液体の 赤外線吸収はかなり強度変化す る。とくに 789, $767 \mathrm{~cm}^{-1}$ の組 の強度は逆転し，また 878，932， $1342 \mathrm{~cm}^{-1}$ の強度がかなり増し， 逆に $1136,577 \mathrm{~cm}^{-1}$ の強度が減 少する。

このような強度変化と少数では あるが重要なスペクトルの消失か 


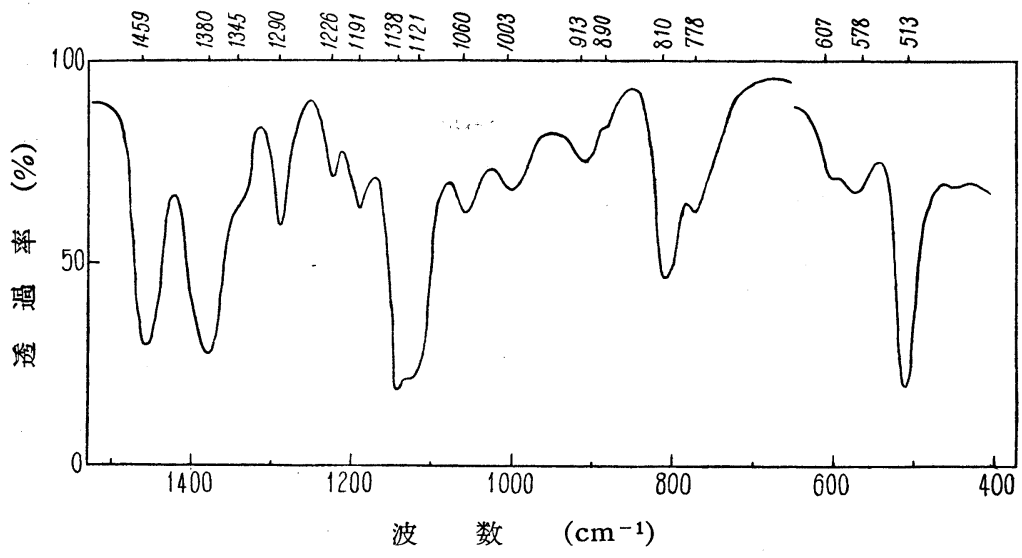

気体：1500～600 $\mathrm{cm}^{-1}$ 室温に扣ける飽和圧 $600 \sim 400 \mathrm{~cm}^{-1}$ 約 $70^{\circ} \mathrm{C}$ 亿加熱

第 4 図 tert-臭化アミルの赤外線吸収

\section{分子形決定のための基準 振動の計算}

回転異性体の分子形の考察のた めにはこのような分子に対しては 基準振動の計算を第一に考えなけ ればならない。なぜなら 1,2-シ クロル-2-メチルプロパン等上異 なり $\left(\mathrm{CH}_{3}\right)_{2} \mathrm{CXCH}_{2} \mathrm{CH}_{3}$ 形の分子 では分子形が異なってもその双極 子能率に変化なく, このため溶媒 による強度変化は期待できず，こ 机によって実験的に分子形を決定 することができないからである。

基準振動の計算はメチル基，メ チレン基を質点として取扱い 6 体
ら液体で 2 種の回転異性体が存在し, 固体ではとのうち 一方のみになることは確実である。

気体においても 2 種の回転異性体が共存することは固 体で消失する $583 \mathrm{~cm}^{-1}$ のスペクトルが赤外線吸収で 存在することから明らかである。

さらに tert-塩化アミル，tert-臭化アミルともに液体 の赤外線吸収が, 約 $150^{\circ} \mathrm{C}$ 程度の温度差により強度変 化することは，存在する 2 種の異性体の安定性法必ずし も同一でないことを示している。この点については別に 報告する。
問題として行った。そのくわしい結果は別に報告する が3)，このためにメチル基，メチレン基の水素変角振動 の影響は無視され，この影響を強くうける C-C 伸縮振 動等には計算值，実測值に不一致がみられる。しかし第 3 表に示すように分子形決定に重要な骨格变角振動汭よ く一致している。この一致から 2 種の分子形が $\mathrm{X} \cdots \mathrm{CH}_{3}$ に関してトランス形，中間形であることが確実となる。 固体での分子形は中間形であることがわかるが，この点 に関しては後に詳しく論ずる。

第 3 表 $\quad\left(\mathrm{CH}_{3}\right)_{2} \mathrm{CXCH}_{2} \mathrm{CH}_{3} \quad(\mathrm{X}=\mathrm{Cl}, \mathrm{Br})$ の実測值と計算值 $\quad\left(\mathrm{cm}^{-1}\right)$

\begin{tabular}{|c|c|c|c|c|c|c|c|c|}
\hline \multicolumn{4}{|c|}{$\left(\mathrm{CH}_{3}\right)_{2} \mathrm{CClCH}_{2} \mathrm{CH}_{3}$} & \multicolumn{4}{|c|}{$\left(\mathrm{CH}_{3}\right)_{2} \mathrm{CBrCH}_{2} \mathrm{CH}_{3}$} & \multirow{3}{*}{ 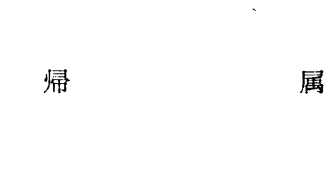 } \\
\hline \multicolumn{2}{|c|}{ トランス形 } & \multicolumn{2}{|c|}{ 中 間 形 } & \multicolumn{2}{|c|}{ トランス形 } & \multicolumn{2}{|c|}{ 中 間 形 } & \\
\hline 実測值 & 計算値 & 実測值 & 計算值 & 実测值 & 計算值 & 実測值 & 計算值 & \\
\hline 613 & 667 & 558 & 621 & 583 & 630 & 513 & 567 & $\mathrm{C}-\mathrm{X}$ 伸縮振動 \\
\hline 933 & 1011 & 914 & 915 & 932 & 974 & 912 & 877 & $\mathrm{C}-\mathrm{C}$ 伸縮振動 \\
\hline 1006 & 1085 & 1061 & 1086 & 1004 & 1061 & 1058 & 1058 & C - C 伸縮振動 \\
\hline 769 & 891 & 796 & 999 & 767 & 908 & 789 & 996 & C-C 伸縮振動 \\
\hline 365 & 359 & 334 & 321 & 329 & 352 & 310 & 310 & $\left(\mathrm{CH}_{3}\right)_{2} \mathrm{C}$ 骨格はさみ振動 \\
\hline 418 & 425 & 235 & 249 & 390 & 367 & 329 & 345 & $\left(\mathrm{CH}_{3}\right)_{2} \mathrm{C}$ 骨格縦りれ振動 \\
\hline 305 & 306 & 124 & 124 & 290 & 291 & 195 & 187 & $\mathrm{CCCl}$ 変角振動（同位相） \\
\hline 235 & 204 & 490 & 490 & 195 & 186 & 480 & 475 & $\mathrm{CCCl}$ 変角振動（逆位相） \\
\hline 1283 & 1091 & 1283 & 1112 & 1285 & 1081 & 1285 & 1101 & C-C 伸縮振動 \\
\hline 305 & 314 & 305 & 265 & 290 & 281 & 226 & 214 & $\left(\mathrm{CH}_{3}\right)_{2} \mathrm{C}$ 骨格ひねり振動 \\
\hline 400 & 414 & 365 & 396 & 403 & 400 & 390 & 399 & $\left(\mathrm{CH}_{3}\right)_{2} \mathrm{C}$ 骨格横ゆれ振動 \\
\hline
\end{tabular}

(3 林, 本誌, 78, 1743 (1957). 


\section{振動スペクトルの临属}

骨格变角振動

この帰属は基準振動の計算結果から知られる。tert臭化アミルの $131 \mathrm{~cm}^{-1}$ には対応する計算值なく，骨格 変角振動ではなく骨格ねじれ振動 (Torsion) と推定さ れる。他の振動は 2 種の異性体に由来するものとしてつ ぎのように分けられる。

tert-塭化アミル: トランス形 $(235,305,365,400$, $\left.418 \mathrm{~cm}^{-1}\right)$ ここで $305 \mathrm{~cm}^{-1}$ は 2 本のスペクトルが重 なったものである。

中間形 $\left(124,235,305,334,365,490 \mathrm{~cm}^{-1}\right)$ 。

tert-臭化アミル：トランス形 $(195,290,329,390$, $\left.403 \mathrm{~cm}^{-1}\right)$ 。ここで $290 \mathrm{~cm}^{-1}$ は 2 本のスペクトルの重 なったものである。

中間形 $\left(195,226,310,329,390,480 \mathrm{~cm}^{-1}\right)$ 。

これらの振動の振動型は基準振動の計算結果から知ら れる。第 3 表にこれを示した。

この表で $\left(\mathrm{CH}_{3}\right)_{2} \mathrm{C}$ 骨格はさみ振動等の表現は〉 $\mathrm{C}\left(\mathrm{CH}_{3}\right)_{2}$ の原子団をメチンン基のごとくみなし， 4 種の $\mathrm{CCC}$ 変 角振動がメチレン基水素変角振動の振動型と同じもので 近似的に表わしうることを示す。また $\mathrm{CCC} 1$ 変角振動は 2 種の $\mathrm{CCCl}$ 原子価角の变化が同位相，逆位相の 2 種の 振動型で表わしうる3)。

C-X 伸縮振動：1,2-ジクロル-2-メチルプロパン1), 1,2-ジクロル-2-メチルプロパン2)の報告ですでに述べ たが， $\left(\mathrm{CH}_{3}\right)_{2} \mathrm{CXCH}_{2} \mathrm{CH}_{3}$ 形分子では $\mathrm{C}-\mathrm{X}$ 伸縮振動は 1 種のみであり,これは他の $\underset{\mathrm{X}}{\mathrm{CH}_{3}-\mathrm{CH}_{3}-\mathrm{CH}_{2}-}$ 構造をもつ 分子においてみられる位置にある。すなわち $\mathrm{C}-\mathrm{Cl}$ 伸 縮振動注 $570 \sim 620 \mathrm{~cm}^{-1}, \mathrm{C}-\mathrm{Br}$ 伸縮振動は 500〜600 $\mathrm{cm}^{-1}$ にある。

メチレン基, $x$ チル基水素変角振動については tert塩化ブチル, tert-臭化ブチル， 1,2-ジクロル-2-メチル プロパン，1,2-ジブロム-2-メチルプロパンの 結果と比 較すれ証比較的簡単に決定できる。さらに液体の赤外線 吸収の温度変化による強度の变化はこの帰属をさらに容 易にする。液体での安定形が $\left(\mathrm{CH}_{3}\right)_{2} \mathrm{CXCH}_{2} \mathrm{X}(\mathrm{X}=\mathrm{Cl}$, $\mathrm{Br})$ と $\left(\mathrm{CH}_{3}\right)_{2} \mathrm{CXCH}_{2} \mathrm{CH}_{3}(\mathrm{X}=\mathrm{Cl}, \mathrm{Br})$ で異なり, 前 者はトランス形, 後者は中間形が常温でスペクトルの強 度が強いので $\left(\mathrm{CH}_{3}\right)_{2} \mathrm{CXCH}_{2} \mathrm{X}$ 形分子の帰属を参考と する時このことに注意する必要がある。

以上帰属の結果注第 1,2 表の最後の闌に示した。 $\left(\mathrm{CH}_{3}\right)_{2} \mathbf{C X C H}_{2} \mathbf{Y}$ 形分子の比較亡固体での分子形 これまで tert-塩化アミル, tert-臭化アミルともに固
体での分子形が中間形であることが確定したものとして 議論を進めて来た。しかし $\left(\mathrm{CH}_{3}\right)_{2} \mathrm{CXCH}_{2} \mathrm{CH}_{3}$ 形分子で は分子形の決定が実験的には行うことができないので， この推定は基準振動の計算結果をただ一つの根処として いる。したがってもう一度この点を他の同形式分子との 比較から議論しよう。

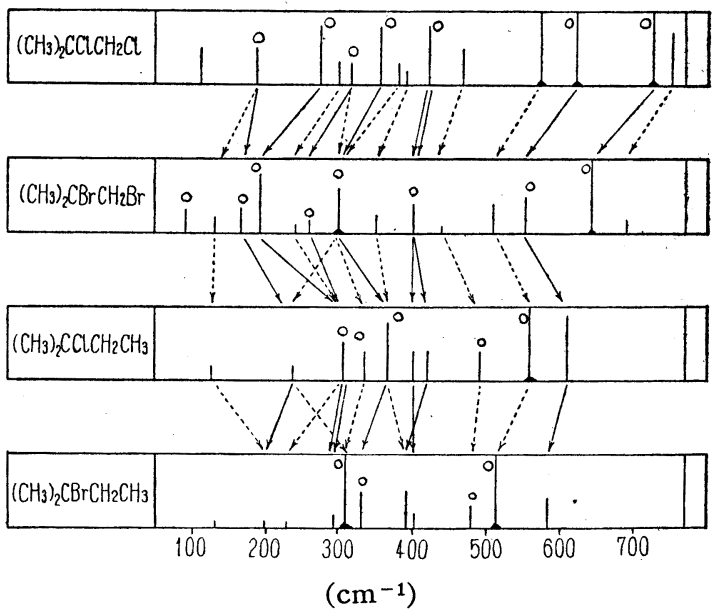

○：固体で存在するもの， $\rightarrow:$ トランス形 $\rightarrow$ : 中間形

第 5 図 $\left(\mathrm{CH}_{3}\right)_{2} \mathrm{CXCH}_{2} \mathrm{Y}$ 形分子のラマン スペクトルの比較

第 5 図に 1,2-ジクロル-2-メチルプロパン，1,2-ジブ ロム-2-メチルプロパン, tert-塩化アミル, text-臭化ア ミルの $700 \mathrm{~cm}^{-1}$ 以下にあるラマンスペクトルを示す。 矢印は基準振動の計算から知られた振動型の同じスペク トルを結ぶ。これをみると $\left(\mathrm{CH}_{3}\right)_{2} \mathrm{CXCH}_{2} \mathrm{X}$ と $\left(\mathrm{CH}_{3}\right)_{2}$ ・ $\mathrm{CXCH}_{2} \mathrm{CH}_{3}$ とは山っきりした差がみとめられる。

i) $\left(\mathrm{CH}_{3}\right)_{2} \mathrm{CXCH}_{2} \mathrm{X}(\mathrm{X}=\mathrm{Cl}, \mathrm{Br})$ の 2 分子または $\left(\mathrm{CH}_{3}\right)_{2} \mathrm{CXCH}_{2} \mathrm{CH}_{3}(\mathrm{X}=\mathrm{Cl}, \mathrm{Br})$ の 2 分子間の骨格変 角振動 $\left(500 \mathrm{~cm}^{-1}\right.$ 以下) と C-X 伸縮振動 $500 \sim 600$ $\mathrm{cm}^{-1}$ はおのおのかなり強度の点，そのならび方に類似 がみられるのに対し $\left(\mathrm{CH}_{3}\right)_{2} \mathrm{CXCH}_{2} \mathrm{X}$ と $\left(\mathrm{CH}_{3}\right)_{2} \mathrm{CX}$ ・ $\mathrm{CH}_{2} \mathrm{CH}_{3}$ を比較した時にはこの差が大きい。

ii ）固体で存在するスペクトル（O印）のならび方が 全体として $\left(\mathrm{CH}_{2}\right)_{3} \mathrm{CXCH}_{2} \mathrm{X}$ と $\left(\mathrm{CH}_{3}\right)_{2} \mathrm{CXCH}_{2} \mathrm{CH}_{3}$ で は差がある。

以上の差についてさらに詳しく検討すると，たとえば $\mathrm{C}-\mathrm{X}$ 伸縮振動で同じ振動型で同じ分子形に属するもの は，計算の結果から $572 \rightarrow 509 \rightarrow 558 * \rightarrow 513^{*} \mathrm{~cm}^{-1}$ (中間 形), $621^{*} \rightarrow 552^{*} \rightarrow 613 \rightarrow 583 \mathrm{~cm}^{-1}$ (トランス形)，(ただ ᄂ $\left(\mathrm{CH}_{3}\right)_{2} \mathrm{CClCH}_{2} \mathrm{Cl},\left(\mathrm{CH}_{3}\right)_{2} \mathrm{CBrCH}_{2} \mathrm{Br},\left(\mathrm{CH}_{3}\right)_{2} \mathrm{CCl}$. $\mathrm{CH}_{2} \mathrm{CH}_{3},\left(\mathrm{CH}_{3}\right)_{2} \mathrm{CBrCH}_{2} \mathrm{CH}_{3}$ の順仁記す。以下も同じ 
順で記す)。ここで固体で存在するものは *を付したが $\left(\mathrm{CH}_{3}\right)_{2} \mathrm{CXCH}_{2} \mathrm{X},\left(\mathrm{CH}_{3}\right)_{2}$. $\mathrm{CXCH}_{2} \mathrm{CH}_{3}$ でちようど逆転する。これは 州属の順を变えれば，すなわち $572 \rightarrow 509$ $\rightarrow 613 \rightarrow 583 \mathrm{~cm}^{-1}$ (中間形) $621^{*} \rightarrow 552^{*} \rightarrow$ $558^{*} \rightarrow 513^{*} \mathrm{~cm}^{-1}$ (トランス形） とすれば よいが計算の結果は無視しなければならな い。同様なことは骨格変角振動にもみられ る。たとえば $468 \rightarrow 438 \rightarrow 490 * \rightarrow 480 * \mathrm{~cm}^{-1}$ (中間形), $420 * \rightarrow 402^{*} \rightarrow 400 \rightarrow 403 \mathrm{~cm}^{-1}$ ( 卜 ランス形)，また不完全ではあるが $420 * \rightarrow$ $402^{*} \rightarrow 418 \rightarrow 390 \mathrm{~cm}^{-1}$ (トランス形), 393 $\rightarrow 349 \rightarrow 365^{*} \rightarrow 390 \mathrm{~cm}^{-1}$ (中間形), 191* $\rightarrow$

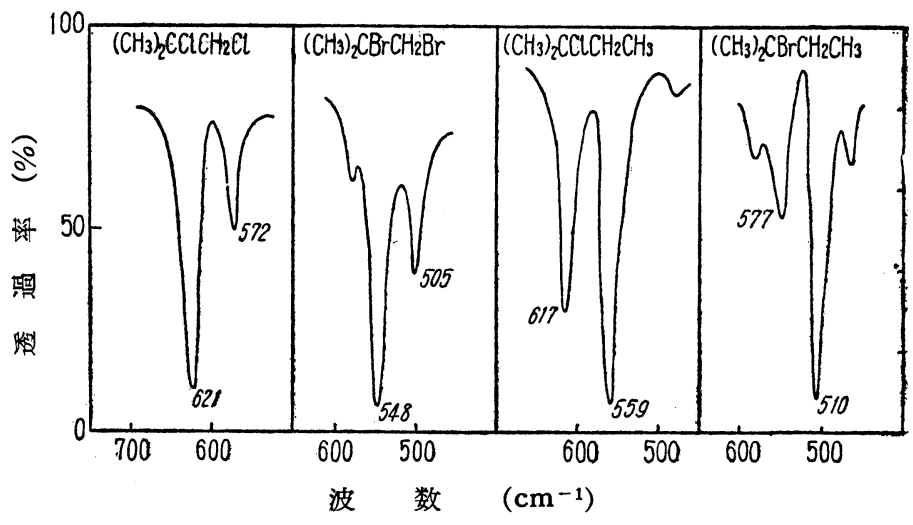

第 6 図 C-X 伸縮振動の赤外線吸収（液体）

$165 * \rightarrow 235 \rightarrow 195 \mathrm{~cm}^{-1}$ (トランス形) 等にもみられる。 したがって C-X 伸縮振動の帰属をかえるためには，こ れらの帰属をも大きく変更させる必要がある。これは基 準振動の計算結果を完全に無視しないかぎり不可能であ る。つぎに赤外線吸収の強度関係を $\mathrm{C}-\mathrm{X}$ 伸縮振動で考 察する。第 6 図に $500 \sim 600 \mathrm{~cm}^{-1}$ 付近の液体の吸収を 示す。これをみると低波数のものと高波数のものの相対 比が $\left(\mathrm{CH}_{3}\right)_{2} \mathrm{CXCH}_{2} \mathrm{X}$ と $\left(\mathrm{CH}_{3}\right)_{2} \mathrm{CXCH}_{2} \mathrm{CH}_{3}$ の分子で逆 転していることがわかる。 $\left(\mathrm{CH}_{3}\right)_{2} \mathrm{CXCH}_{2} \mathrm{X}$ ではこのう ち低波数のものが固体で消失する。 $\left(\mathrm{CH}_{3}\right)_{2} \mathrm{CXCH}_{2} \mathrm{CH}_{3}$ では固体の測定はできなかったが，その温度变化による 強度の变化のようすからえられる推定によると, 前にラ マンスペクトルからえられたと同じ結論となる。メチレ ン基, メチル基水素変角振動についても同じ結論をうる。 この一連の事実は $\left(\mathrm{CH}_{3}\right)_{2} \mathrm{CXCH}_{2} \mathrm{X}$ と $\left(\mathrm{CH}_{3}\right)_{2} \mathrm{CX}$. $\mathrm{CH}_{2} \mathrm{CH}_{3}$ とで固体での 分子形が異なると考えることに
より完全に理解できる。 $\left(\mathrm{CH}_{2}\right)_{3} \mathrm{CXCH}_{2} \mathrm{X}$ ではトランス 形が固体における分子形であることは溶媒効果から確定 していた。したがって $\left(\mathrm{CH}_{3}\right)_{2} \mathrm{CXCH}_{2} \mathrm{CH}_{3}$ では中間形 が固体での分子形であると結論できる。

このように $\left(\mathrm{CH}_{3}\right)_{2} \mathrm{CXCH}_{2} \mathrm{X},\left(\mathrm{CH}_{3}\right)_{2} \mathrm{CXCH}_{2} \mathrm{CH}_{3}$ で 固体での分子形が異なることは非常に興味がある。この 原因は簡単に推定するわけに行かない。しかし気体にお いてはその温度変化による強度変化のようすをみると， 常温では $\left(\mathrm{CH}_{3}\right)_{2} \mathrm{CXCH}_{2} \mathrm{X}$ はトランス形, $\left(\mathrm{CH}_{3}\right)_{2} \mathrm{CX}$. $\mathrm{CH}_{2} \mathrm{CH}_{3}$ は中間形が他よりも安定であると推定される。 この安定性，すなわち異性体間のエネルギー差に関して は別に報告する。

終りに本研究の御指導をいただいた水島三一郎教授， 島内武彦,市沜 勲両助教授に心から感謝の意を表する。 (昭和 31 年 4 月, 日本化学会第 9 年会(一部)講演)

（東京大学理学部化学教室, 東京都文京区）（昭和 32 年 7 月 25 日受理）

\section{漆原ニッケルによる有機化合物の還元 $\quad(\text { 第 } 3 \text { 報 })^{1)}$}

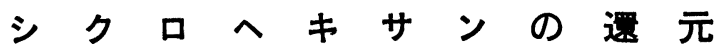

西村重夫

漆原ニッケルによる常温, 常圧に扣けるシクロヘキサノンのエタノール中に打けるシクロへキサ ノールヘの還元を，(1) 濃度と還元速度，(2) 温度と還元速度，(3) アルカリの還元速度に対する 影響, の三つの関係につき定量的に研究し，(1) は Langmuir 型の等温吸着式によく一致し， （2）の関係よりこの還元の見掛けの活性化エネルギーは $5.3 \mathrm{cal} / \mathrm{mol}$ であり，(3) に扎いては， 溶媒のエタノールかフェノールフタレインに淡く棪色に呈色する程度のアルカリを加えた場合に還 元速度が最大になるという結果を得た。

1） 前報 (第 2 報) 西村, 本誌. 78, 1741 (1957). 